\title{
Comparison of Lipopolysaccharide binding protein and C-reactive protein gene expression levels in a Rat model of induced Atherosclerosis
}

\section{Kholoud S. Ramadan"1; Rasha E. Hassan': Abd El Rahman B. Abd El Ghaffar $^{1}$ and Asmaa A. Deghedy ${ }^{1}$}

*Department of Biochemistry, Faculty of Girls Science, King Abdulaziz University, Jeddah, Saudi Arabia,

${ }^{1}$ Department of Biochemistry, Faculty of Science, Ain Shams University, Cairo, Egypt.

\begin{abstract}
:
Introduction:

Atherosclerosis is an inflammatory disease characterized by the accumulation of lipids within arterial walls that eventually go on to form plaques, which can cause narrowing, hardening, and/or complete blockage of arteries. This study was designed to examine the cholesterol feeding induction of cardiovascular diseases exemplified by atherosclerosis in rat and induction of CRP, LBP, SAP and P4H on the transcriptional activity of the inflammation / related gene expression by a semi-quantitative RT-PCR in liver and heart tissues, and make comparison between CRP and LBP as biomarker for atherosclerosis.
\end{abstract}

\section{Material \& Methods:}

Experimental Rats were fed with cholesterol diet (2.5\% pure (wt/wt) cholesterol, $1 \%$ cholic acid and $5 \%$ oil) and sacrificed after 18 weeks of feeding.

\section{Results:}

Histopathological examination for heart showed fatty cells deposition in atherogenic rats. Expression pattern of CRP, LBP, SAP \& P4H genes were investigated, in liver and heart, these genes were highly expressed while some of them showed no expression pattern in heart tissues.

Key words: Cardiovascular diseases, Atherosclerosis, C-reactive protein, Lipopolysaccharide binding protein, Serum amyloid P component \& Prolyl-4-Hydorxylase.

\section{Introduction:}

Atherosclerosis can be regarded as a chronic inflammatory response limited to the vascular bed. New insights into the pathogenesis of atherosclerosis clearly indicate that multiple factors, such as hypertension, high plasma concentrations of low-density lipoprotein (LDL) cholesterol, diabetes mellitus, and infection, influence the development and progression of atherosclerosis (Shehata \& Yousef, 2010). Research over the last 15 years has provided convincing evidence that atherosclerosis has 


\section{Comparison of Lipopolysaccharide binding protein and C-reactive protein....}

typical features of an inflammatory disease. There is unequivocal evidence for a local inflammation in the artery wall which is accompanied by a systemic low-grade inflammatory response. Such response can be measured by a variety of inflammatory biomarkers. The largest database so far has been accumulated for C-reactive protein. More than 25 prospective studies have shown a strong and consistent association between elevated C-reactive protein concentrations and various cardiovascular endpoints. In addition, evidence from in vitro and clinical studies suggest that $\mathrm{C}$ reactive protein might also be implicated in the pathophysiology of atherogenesis, which, however, still represents a controversial issue (Kolz et al., 2008). Creactive protein (CRP) is an acute phase reactant with roles in innate host defense, clearance of damaged cells, and regulation of the inflammatory response. Cytokines released from jeopardized tissues stimulate the liver to synthesize acute phase proteins, including C-reactive protein (CRP) and serum amyloid $\mathrm{P}$ component (SAP). Lipopolysaccharide-binding protein (LBP) was proposed as an additional marker for Coronary Artery Disease (CAD) risk, because LBP can be regraded as a surrogate marker for activated innate immune system, which plays an important role in the pathophysiology of atherosclerosis (Lusis, 2000). Serum amyloid $P$ component (SAP), the murine homologue to $\mathrm{CRP}$, is a relatively low concentration constitutive serum protein in man. Paradoxically, in mouse it is SAP that is a major acute phase reactant. (Jiang et al., 1995) Therefore, mRNA expression levels of CRP and SAP may provide sensitive markers of systemic acute phase response (Saber et al., 2009). Experimental results have demonstrated that the pathogenesis of atherosclerosis is based on several mechanisms. Extracellular matrix (ECM) may have a role in the pathogenesis of atherosclerosis (Libby, 2002). ECM components, especially collagen, are thought to be important in the progression of atherosclerosis. Prolyl-4-hydroxylase $(\mathrm{P} 4 \mathrm{H})$ is a key intracellular enzyme essential for all known types of collagen maturation and secretion (Annunen et al., 1998). The present study sought to evaluate the cholesterol feeding induction of cardiovascular diseases exemplified by atherosclerosis in rat and induction of CRP, LBP, SAP and $\mathrm{P} 4 \mathrm{H}$ gene expression in liver and heart tissues.

\section{MATERIAI AND METHODS}

\section{Experimental animals:}

Ten weeks old male Swiss albino rats $(\mathrm{n}=30)$ weighing 150-200 $\mathrm{g}$ were maintained on a diet of ad libitum and tap water. These experiments have been approved by Ain Shams University committee on the use and care of Laboratory animals. After 2-weeks 
as a conditioning period, the animals were randomly distributed into 2 groups. One group $(\mathrm{n}=10)$ was treated as a control group, left without cholesterol feeding. The other group $(n=20)$ was treated as the experimental group( high cholesterol diet group (HCD) and were fed with standard rat chow supplemented with $2.5 \%$ pure (wt/wt) cholesterol, $1 \%$ cholic acid and $5 \%$ oil for 18 weeks.

\section{Tissue specific expression of CRP, LBP, SAP and P4H genes by semiquantitative RT-PCR analysis}

\section{I) RNA extraction from tissue}

RNA was extracted from rat livers and hearts according to the method of Nicholas, (2004) using BIOZOL BioFlux ${ }^{\mathrm{TM}}$ Reagent (ready to use) that was purchased from BioFlux (South San Francisco, U.S.A).

\section{II) Reverse transcription}

The extracted total RNA was then reverse transcribed with Oligo $\mathrm{d}(\mathrm{T})$ primer according to Revert Aid First Strand cDNA Synthesis $\mathrm{Kit}^{\mathrm{TM}}$ (purchased from Fermentas life science Co. (Invitrogen Corporation) (Van Allen Way, Carlsbad, Canada). Positive and negative control reactions were used to verify the results of the first strand cDNA synthesis steps. GADPH gene RNA was used as positive control.

\section{III) Polymerase chain reaction}

The resulting cDNA was subjected to PCR for 35 cycles with respective primers designed from the sequence of the CRP, LBP, SAP and P4H genes (table 1) using primer 5.0 software and were purchased from Invitrogen Corporation (Van Allen Way, Carlsbad, Canada). Dream $\mathrm{Taq}^{\mathrm{TM}}{ }^{\mathrm{T}}$ reen PCR Master Mix (Invitrogen Corporation) was used in the PCR. Products are then displayed on an appropriate agarose gel $(2 \%)$ and examined for yield and specificity. Analysis of gel images was done using Gel analyzer Pro (version 3.1) software. PCR product for each gene was sequenced. The obtained nucleotide sequences were blasted on gene bank site (http://www.ncbi.nlm.nih.gov/) to ensure that the obtained PCR product is our target gene. The nucleotide sequence for each gene was analyzed by using the web site for sequence manipulation suite (version 2):http://www.bioinformatics.org/sms2/ to characterize some target genes like the open reading frames, prediction and characterization for the protein sequences and the signal P 3.0 Sever using the expasy website (http://expasy.org/tools/) to predicts the presence and location of signal peptide cleavage sites in amino acid sequence. This method incorporates a prediction of cleavage sites and a signal peptide/nonsignal peptide prediction based on a 


\section{Comparison of Lipopolysaccharide binding protein and C-reactive protein....}

combination of several artificial neural networks and hidden Markov models.

\section{Histochemical diagnosis of myocardial infarction:}

Autopsy samples were taken from the heart of rats in different groups and fixed in $10 \%$ formal saline for 24 hours. Washing was done in tap water then serial dilutions of alcohol (methyl, ethyl and absolute ethyl) were used for dehydration. Specimens were cleared in xylene and embedded in paraffin at $56{ }^{\circ} \mathrm{C}$ in hot air oven for 24 hours. Paraffin bees wax tissue blocks were prepared for sectioning at 4 microns by slide microtome. The obtained tissue sections were collected on glass slides, deparaffinized and stained by hematoxylin and eosin stains (Banchroft et al., 1996) for histopathological examination through the lightmicroscope.

\section{RESULTS:}

Table (1): Sequences of the 5' and 3' synthetic primers used in PCR.

\begin{tabular}{|c|c|c|}
\hline $\begin{array}{l}\text { Gene \& its accession } \\
\text { number }\end{array}$ & $\begin{array}{l}\text { Primers (sense and antisense } \\
\left.5^{\prime} \rightarrow 3^{\prime}\right)\end{array}$ & $\begin{array}{l}\text { Anneal-ing } \\
\text { Temp. }\end{array}$ \\
\hline $\begin{array}{l}\text { CRP } \\
\text { M83176 }\end{array}$ & $\begin{array}{l}\text { Sense: 5'-CGA AGC TTC AGC } \\
\text { ATC TTC TC-3' } \\
\text { Antisense: 5'-CTG CAT TGA } \\
\text { TCT GTT CTG GAG-3' }\end{array}$ & $46.5^{\circ} \mathrm{C}$ \\
\hline LBP & $\begin{array}{l}\text { Sense5'-GAG GCC TGA } \\
\text { TCT CCA TCT-3' } \\
\text { Antisense5'-TCT GAG ATG } \\
\text { GCA AAG TAG ACC-3' }\end{array}$ & $45.7^{0} \mathrm{C}$ \\
\hline SAP & 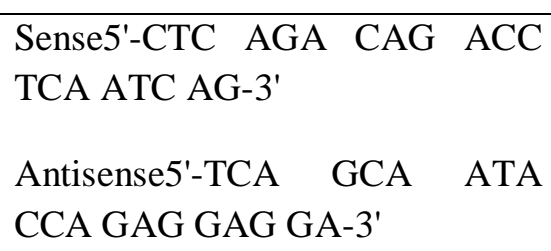 & $41.1^{\circ} \mathrm{C}$ \\
\hline $\mathrm{P} 4 \mathrm{H}$ & $\begin{array}{l}\text { Sense: 5'-CCA GCC AGT TGC } \\
\text { CTT CTT GGG A-3' } \\
\text { Antisense: 5'-GGC ATA GCA } \\
\text { CAC TAG GTT TGC CGA-3' }\end{array}$ & $58{ }^{0} \mathrm{C}$ \\
\hline
\end{tabular}




\section{Kholoud S. Ramadan... et Al}

\section{a) C- reactive protein gene expression:}

CRP gene was highly expressed by hepatocytes and heart in HCD rats after 18 weeks (Fig. 1-A). In both tissues the bands molecular weight on agarose gel were 433 bp. While, there was no expression for CRP in the liver and heart of normal nonatherosclerotic control group. GADPH gene expression was used as + ve control in examining all the studied genes. Rat CRP gene/GADPH gene ratio was determined by densitometry (Fig.2), which was performed by measuring the photo stimulated luminescence values using gel analyzer pro version software. After 18 weeks of cholesterol feeding, the rat CRP gene expression recorded low level compared to the control, in liver and heart. Moreover, rat CRP gene expression level in liver was higher than that of heart. These different levels of expression were showed in (Fig. 3A).

\section{b) Lipopolysaccharide binding protein} gene expression:

LBP gene showed expression by hepatocytes in HCD rats Fig. 1-B). While LBP gene shows no expression in the heart tissue of the HCD rats as in normal control group. The bands molecular weight of LBP genes was $540 \mathrm{bp}$ according to the used marker. After 18 weaks of cholesterol feeding, the rat liver LBP gene expression levels decreased and became less than that of control.These different levels of expression were showed in (Fig. 3-B).

\section{c) Serum myeloid $P$ component gene expression:}

SAP gene was expressed by hepatocytes in the HCD rats. The bands molecular weight of SAP genes were $331 \mathrm{bp}$ (Fig. 4-A) After 18 weaks of cholesterol feeding, the rat SAP gene expression recorded high level compared to the control. Heart tissue shows no expression for SAP gene as in normal control group. These different levels of expression were showed in Fig. (5-A).

\section{d) Prolyl 4 Hydorxylase- $\beta$ polypeptide gene expression:}

$\mathrm{P} 4 \mathrm{H}-\beta$ gene was expressed by hepatocytes in the HCD rats Fig. (4 -b). Heart tissue also shows no expression for $\mathrm{P} 4 \mathrm{H}-\beta$ gene. The bands molecular weight of $\mathrm{P} 4 \mathrm{H}-\beta$ genes was 850 bp. After 18 weeks of cholesterol feeding, the rat $\mathrm{P} 4 \mathrm{H}-\beta$ gene expression recorded low level compared to the control. Heart tissue showes no expression in HCD groups as in normal control group. These different levels of expression were shown in Fig. (5 -B). 
Comparison of Lipopolysaccharide binding protein and C-reactive protein....
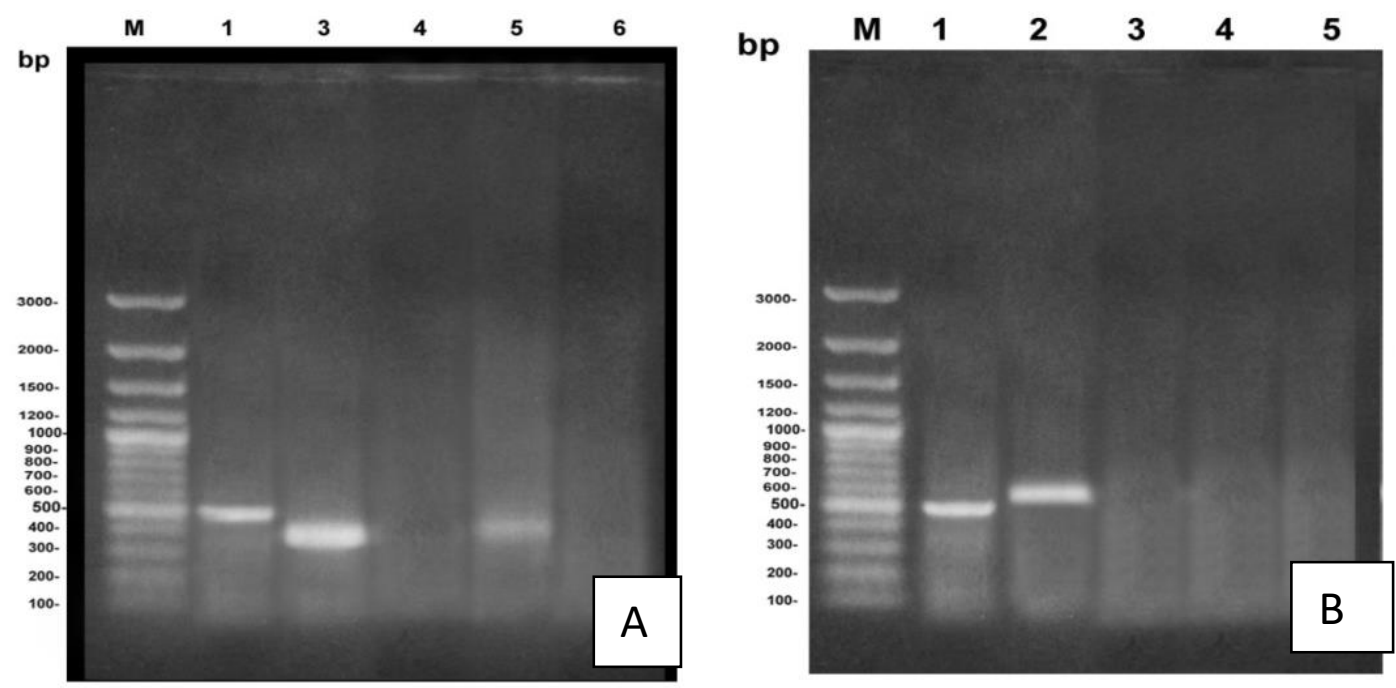

Figure (1): A)The C-reactive protein (CRP) gene expression in accordance to GADPH. (B) LBP gene expression in accordance to GADPH (lane: 1) obtained by RT-PCR in liver (lane: 2) \& heart (4) of HCD groups and control group (lanes $3 \& 5$ ) (M: DNAmarker).

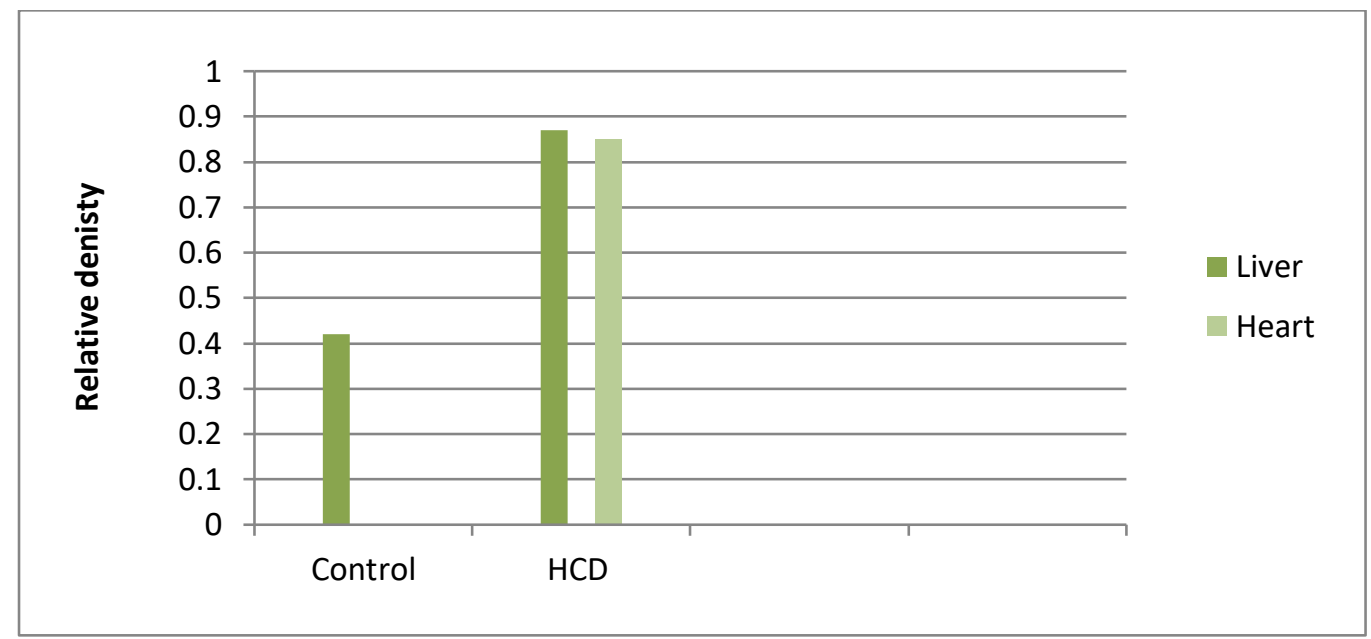

Figure (2): The relative density of expressed rat CRP gene bands in liver and heart tissues. 
Kholoud S. Ramadan... et Al
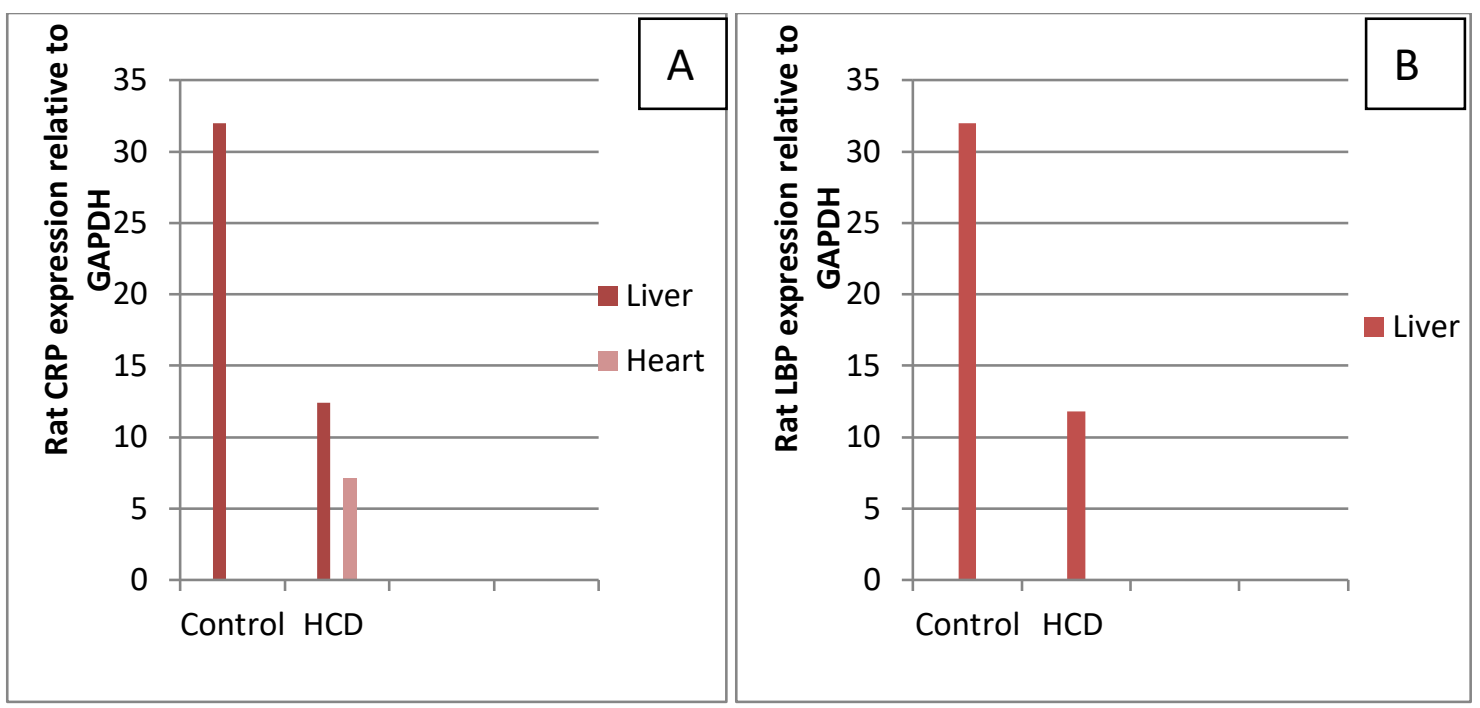

Figure (3): (A) Effect of cholesterol feeding on expression of rat CRP \& GADPH genes in liver and heart. (B): Effect of cholesterol feeding on expression of rat LBP \& GADPH genes in liver.
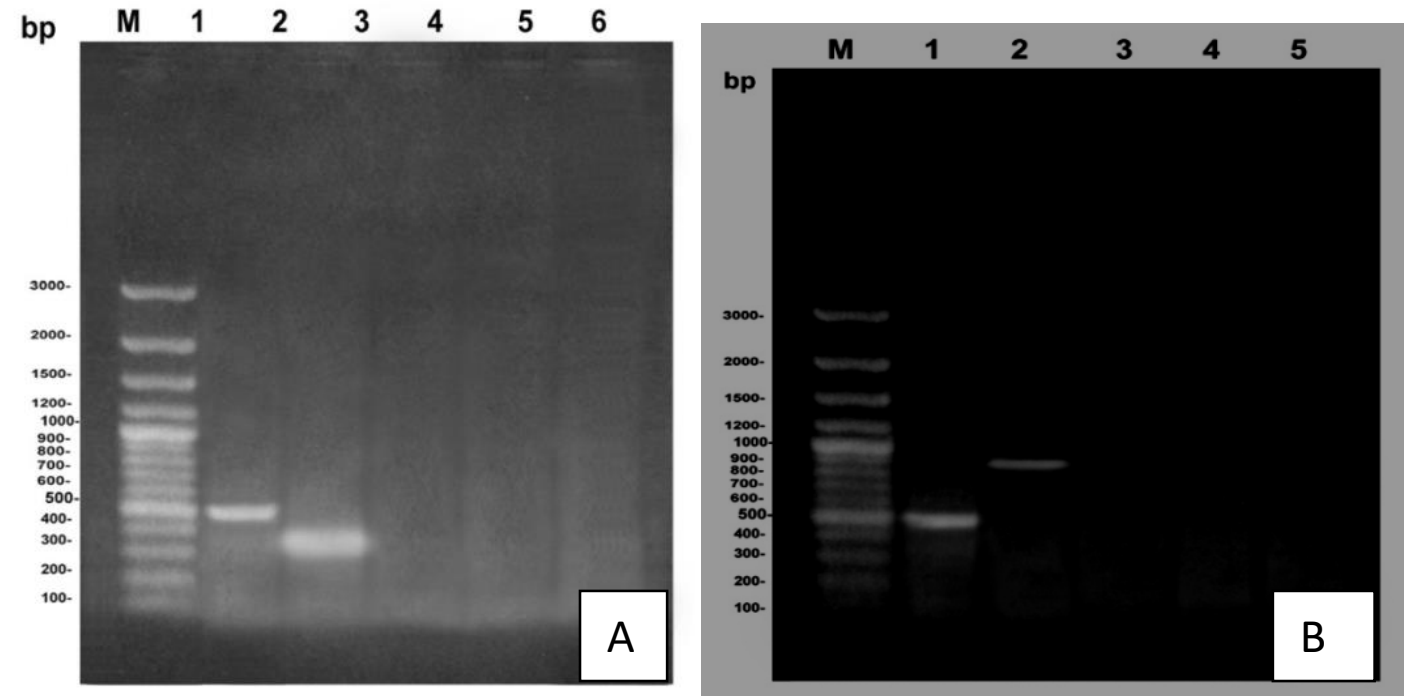

Figure (4): (A) SAP gene expression in accordance to GADPH. (B) P4H gene expression in accordance to GADPH (Lane: 1) obtained by RT-PCR in liver (2) \& heart (4) of HCD group and control group (3 \& 5) (M: DNA marker). 


\section{Comparison of Lipopolysaccharide binding protein and C-reactive protein....}
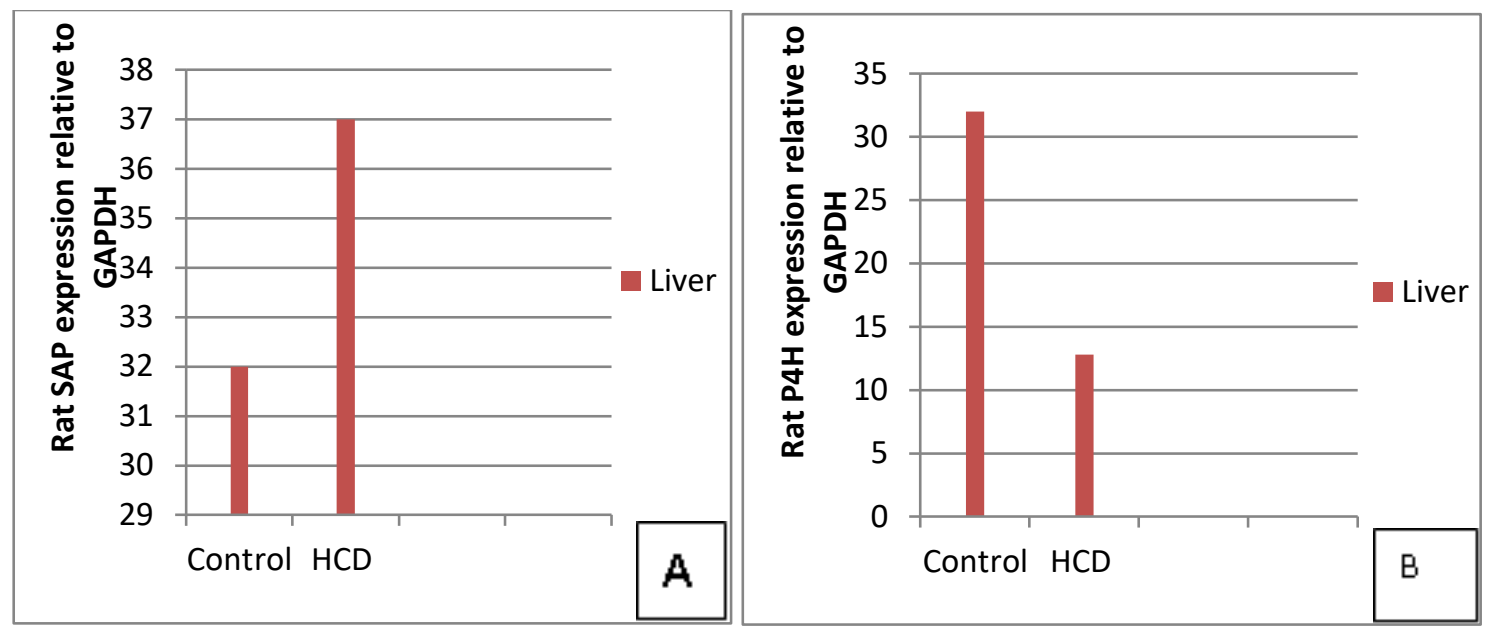

Figure (5): (A) Effect of cholesterol feeding on expression of rat SAP \& GADPH genes in liver. (B) Effect of cholesterol feeding on expression of rat P4H \& GADPH genes in liver.

\section{Analysis of Rat gene sequence}

After detecting the PCR products for each target gene using the agarose gel electrophoresis, the PCR products were sequenced. Then the sequences were blasted on Gene bank using the BLAST tool to ensure that the visualized bands on gel were for our target gene. The analysis of rat target genes sequence was carried out using the web site for sequence manipulation suite (version

2): http://www.bioinformatics.org/sms2/, showed that CRP gene (Fig. 6) consists of 531 bp with three open reading frames (ORF).

1 NGNANNNTNN NANNCTNAAC GAGATTTCTT CCTGTTTTGG ACNTNGGGGT TCCAAGGGGT TTTAGTTATT TGCAGTAGGT 81 GGGCCTGAAA TACTGTTCAG TGCTTCAGAA AATTCCTGAA GGTACCAACA CACATCTGTG CCACCTGGGA GTCTGCTACA 161 GGAATTGTAG AGCTTTGGCT TGACGGGAAA CCCAGGGTGC GGAAAAGTCT GCAGAAGGGC TACACTGTGG GGACAAATGC 241 AAGCATCATC TTGGGGCAGG AGCAGGACTC GTATGGCGGT GGCTTTGACG CGAATCAGTC TTTGGTGGGA GACATTGGAG 321 ATGTGAACAT GTGGGACTTT GTGCTATCTC CAGAAAAACG CAATTCATAG TCTACAAATA GGTAAATATT GTTACAACTT 401 TTAAATAAGT AAGAGTTTGT GGTGGATGCC TTGGGTTAGT ATTTACACGA CGTTTCCCGA AGAGACATAA GAATTAATCT 481 GAGCTTGTTT ATGGATTTAA AAAAACCCAA CCTGGTGGAG GTGATGGGAT G

Figure (6): The complete nucleotide sequence of rat CRP gene.

The ORF number 1 on the direct strand extends from base 79 to base 183. ORF number 2 on the direct strand extends from base 184 to base 288 and ORF number 3 on the direct strand extends from base 289 to base 381. Using the translation tool, nucleotide sequence of rat CRP gene was translated into 177 amino acid. The predicted protein molecular weight was $43.40 \mathrm{KDa}$ and its isoelectric point was $\mathrm{pH}$ 


\section{Kholoud S. Ramadan... et Al}

5.07. The signalP-NN and SignalP-HMM results showed that the protein is nonsecretory protein with signal peptide probability (0.001) and maximum cleavage site probability $(0.00)$ between position 34 and 35. with three open reading frames (ORF). ORF number 1 on the direct strand extends from base 67 to base 171. ORF number 2 on the direct strand extends from base 172 to base 264. ORF number 3 on the direct strand extends from base 499 to base 630 .

Analysis of rat LBP gene sequence showed that LBP gene consists of 632 bp (Fig 7)

Figure (7): The complete nucleotide sequence of rat LBP gene

Translation of LBP revealed 110 amino acids predicted LBP protein molecular weight was $51.90 \mathrm{KDa}$ and its isoelectric point was $\mathrm{pH}$ 4.95. The signalP-NN and SignalP-HMM results showed that the protein is non-secretory protein with signal peptide probability (0.076) and maximum cleavage site probability (0.009) between position 60 and 61 .

Nucleotide sequence of rat SAP gene (Fig. 8) showed that SAP gene consists of $950 \mathrm{bp}$ with three open reading frames (ORF). ORF number 1 on the direct strand extends from base 190 to base 291. ORF number 2 is on the direct strand extends from base 397 to base 696.ORF number 3 on the direct strand extends from base 772 to base 888 . 


\section{Comparison of Lipopolysaccharide binding protein and C-reactive protein....}

1 GNTCTNCNTN TCCNAGATCT GAACTGATTA TGTGAAGCTG ATCCCATGgC TAGAAAAACC GCTGCAGAAT TTTACACTGT

81 GTTTCCGAGC CTACAGTGAC CTTTCCCGCT CTCAGAGTCT TTTCTCCTAC AGTGTCAACA GCAGAGACAA TGAGCTACTA

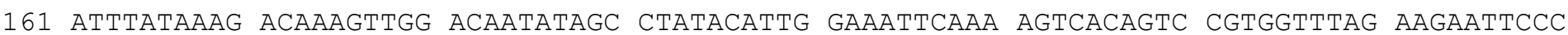

241 TTCTCCAATA CATTTCTGTA CCAGCTGGGA GTCCTCCTCA GGTATTGCTG AgGATAATGT CCTCCGGGAT TCTGACATAA

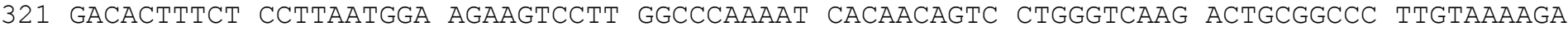

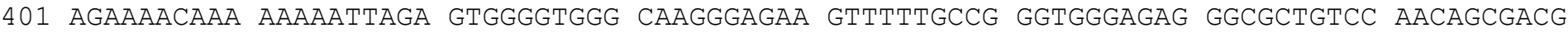

481 TTCATTTTGT GgTACCCGgC TTCCGgGCCT CGgCTAAGA CGgAtAATGC GgCGTGCAAA AAAAAAAAA CCGTGGGCAA

561 GAGACATAGA AAGGAAAAAG GATGGGACAA CAGAAAAAAA AAAAGAATAA AAAATGTCAA TGTAAAAGAG GTCAACGTGA

641 AAAAACTCAC TCCTCTCTGG AATTTTAACT TCTTTAAGAN TGACCTGAAT ACATAAACTA CCCAAATAAG AATCACTAAT

721 AAAgTTATAG AATAAAAACA AAAAAAATGC ATAGGTACTG AAACAACATG AGAGTACAAA AAACAAATAC GAAANAANAC

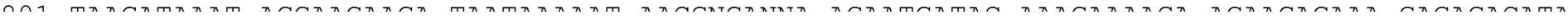

Figure (8): The complete nucleotide sequence of rat SAP gene

Translation of SAP nucleotides into 316

amino acids predicted protein molecular weight as $77.07 \mathrm{KDa}$ and its isoelectric point was $\mathrm{pH}$ 4.92. The predicted signalP-NN and SignalP-HMM for the predicted protein of SAP results showed that the protein is nonsecretory protein with signal peptide probability (0.092) and maximum cleavage site probability $(0.028)$ between position 57 and 58.
Analysis of rat $\mathrm{P} 4 \mathrm{H}-\beta$ gene sequence (Fig.9) showed that $\mathrm{P} 4 \mathrm{H}-\beta$ gene consists of $767 \mathrm{bp}$ with four open reading frames (ORF). ORF number 1 on the direct strand extends from base 1 to base 108. ORF number 2 on the direct strand extends from base 109 to base 408 , the ORF number 3 on the direct strand extends from base 409 to base 561 and finally ORF number 4 on the direct strand extends from base 610 to base 765 .
ANNNNAANNA CNNTNAGAAC

81 GAGTGAAAGC TGTCCAAGCC TGGCCTGAAA A

161 AAAAAAAGAA AAAAAAAAAA AAAAAAAAAA AAAAAAACTA

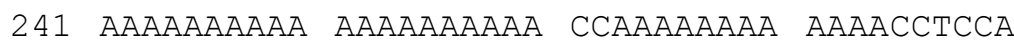

321 AAAAACAAGA ACCACGACAA AAAAAAAAAA ACAAGAAGAT

401 ACCTCTAAAA CAGGAAAAAA AAAAAAAAAT GTGAAATCCC

481 AAAAAGTACA CCACCAAATT AAAACAAAAC GTAACCCTTC

561 AAAAGCAAAA AAAGAAGAAG ACAGGTTTAA GTGTACGTGT

641 ATGgCGCTCC CTCCTGgggt GAgGCTCAgG CTCCGgAgAT

721 GGCGCCCAGA

CTCTGGGGT

CTCCGGAGAT
TGCCCAAGCC

AAAAAAAAAA

CAAAAACCAT

GAAAAAGGAA

GAAACATCAA

AAAAAATGGT

AAGATGGGCT

GTCAGATGAG

GTCAAA
AGCCGGCTGG ACGGAGTTCT

АAАAAAAAAA АAАAAAАAАA

GCAAAAAAAA AAAAAAATAA

AAAAAAAAAA ATCAAGAAGG

AAAAAAAAAA ATCAGAAGTG

AAAAAGCACT

GGCCTGGACA

TGTGGCTTCA

GGGACATGGC
TGGAAAAAAA

GAGATCCCTT

GAAAGATTCC

CCACCGAGGT
GGCTTAAAAA

АAАAAAAAAA

AACAAAGAAA

AАAAAAAAAA

ATAAAAAAAA

TCCACGTACA

TCCAAAATTG

CTGGGTTCTG

TTTGGGTTCA

Figure (9): The complete nucleotide sequence of rat $\mathrm{P} 4 \mathrm{H}$ gene

The nucleotide sequence of rat $\mathrm{P} 4 \mathrm{H}-\beta$

gene was translated into 343 amino acid sequence using the translate tool. The

predicted protein molecular weight was 
Kholoud S. Ramadan... et Al

$60.39 \mathrm{KDa}$ and its isoelectric point was $\mathrm{pH}$ 4.98. The signalP-NN and SignalPHMM results showed that the protein is non-secretory protein with signal peptide probability (0.073) and maximum By examination of heart tissue from the atherogenic rats, it showed deposition of fat surrounding the heart pericardium specially in the atrium, as well as penetrated in between the chambers of the atrium 10). cleavage site probability (0.015)

between position 51 and 52 .

\section{Histopathological analyses}

associated with inflammatory cells infiltration. The fissures between the atrium showed fatty cells deposition also. There was focal hyalinization with inflammatory cells infiltration in the myocardium (Fig
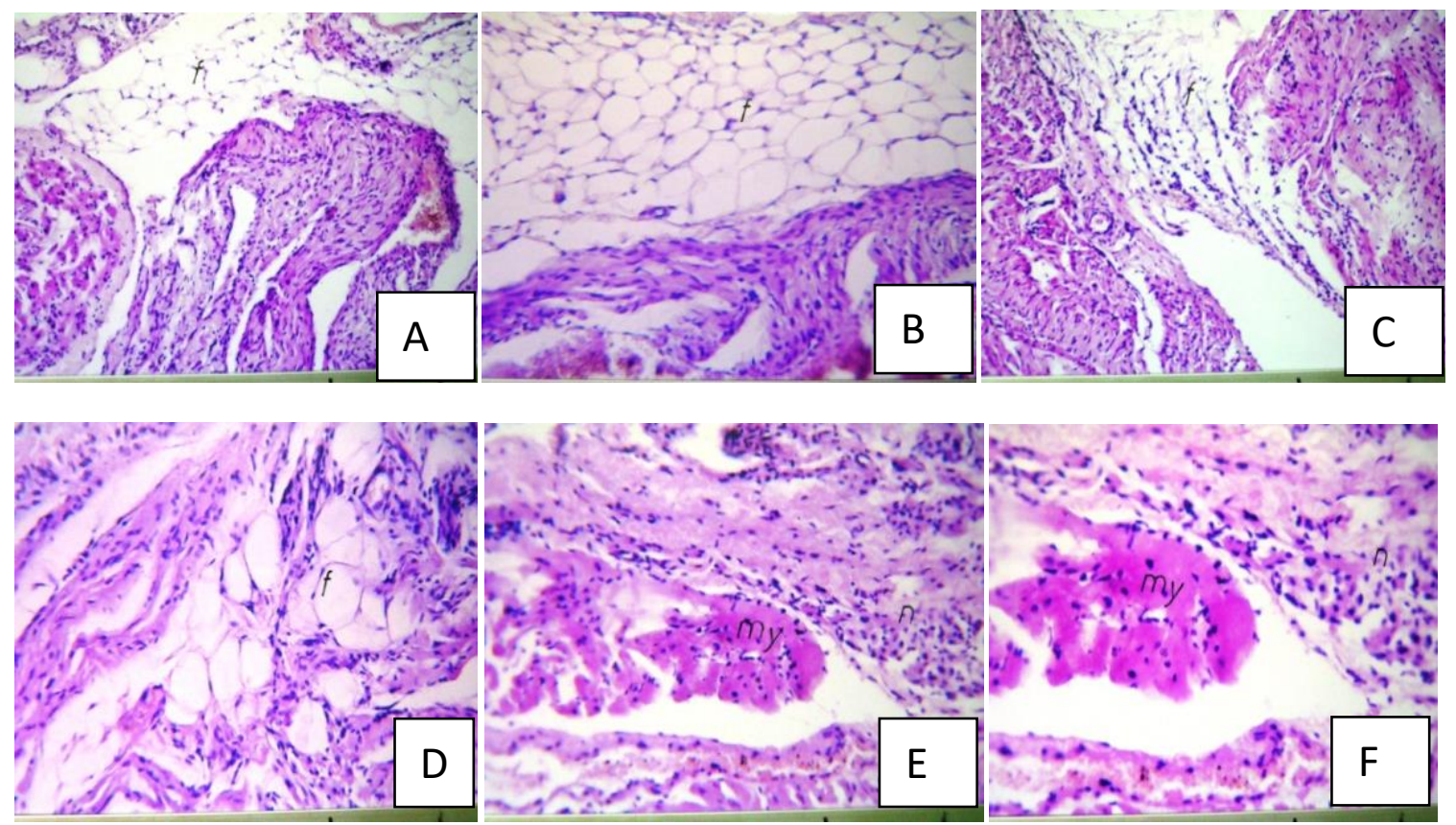

Fig (10): Heart sections of atherogenic rats showed (A) deposition of fat and adipose tissue in between chambers of the atrium with inflammatory cells infiltration; (B) the inflammatory cells infiltration in the fat tissue; (C) penetration of fat cells in between the fissures of the atrium (f); (D) adipoblasts embedded in between the myocardial muscle bundles in the atrium (f); (E) hyalenization of the myocardium (my) with inflammatory cells infiltration (n) at the atrium and (F) the magnification of (E) to identify the hyalenization of the myocardium (my) and inflammatory cells

infiltration

(n)

at

the at 


\section{Comparison of Lipopolysaccharide binding protein and C-reactive protein....}

\section{DISCUSSION}

Atherosclerosis results in Coronary Heart Disease (CHD), one of the major causes of morbidity and mortality. The link between elevated cholesterol and CHD has been clearly established and the National Cholesterol Education Program clinical guidelines for the treatment of hypercholesterolemia identify low density lipoprotein cholesterol as the primary treatment target (Collins et al., 2004).

Epiemiological studies have shown that vascular inflammation is an independent atherosclerotic risk factors. We now appreciate that chronic elevations in circulating C-reactive protein (CRP) and other hepatic acute-phase reactants are independently predictive of atherosclerotic risk and mortality in humans. The hepatic acute phase response alters patterns of plasma proteins by cytokine-induced changes in gene expression by the liver. Components of the innate immune system, CRP and apoliproteins are all established acute-phase reactants and have known cardiovascular effects. These findings have led to the hypothesis that liverderived proteins may participate in the atherogenic process. However, the complete spectrum of genes induced by the liver and their potential roles in atherosclerotic mechanisms have not been systematically studied (Pepys \& Hirschfield 2003).

The present study was concerned with atherosclerosis wher it was carried out on two groups of rats. One group $(n=10)$ was treated as a control group, left without cholesterol feeding. The other group $(n=20)$ was treated as the experimental group. The high cholesterol diet group (HCD) were fed with standard rat chow supplemented with $2.5 \%$ pure (wt/wt) cholesterol, $1 \%$ cholic acid and $5 \%$ oil for 18 weeks. All rats in the experimental group developed atherosclerosis, this was proved, after sacrificing the animals through the histological investigations. In this study we investigated numerous biochemical markers for inflammation and gene expression pattern for group of inflammation related genes.

C-reactive protein is an acute-phase reactant protein synthesized primarily by liver cells in response to the proinflammatory cytokines including interleukin- 6 and TNF- $\alpha$ (Castell et al., 1990). The major function of CRP by binding phosphocholine is to recognize some foreign pathogens and phospholipid constituents in damaged cells. It also activates the complement system and contributes to the induction of inflammatory cytokines and tissue factors in monocytes (Ballou and Kushner, 1992).

Inflammatory molecules as mildly raised Creactive protein (CRP) are among the most extensively studied CVD biomarkers and is considered one underlying cause of CVD development and progression (Libby, 2002). Animal studies also support the 


\section{Kholoud S. Ramadan... et Al}

proinflammatory and pro-atherogenic role of CRP, because administration of human CRP or over-expression of CRP in apolipoprotein E-deficient mice promotes the development of spontaneous atherosclerosis (Paul et al., 2004). CRP is mainly expressed by hepatocytes, but can be synthesized in other tissues (Black et al., 2004 \& Marnell et al., 2005), although the liver has been assumed as the only source of CRP synthesis and release, this protein has been demonstrated (Calabro et al., 2003) to be produced also in other districts, such as the vascular walls.

In the current study, feeding rats on high cholesterol diet induces a "priming" of the host immune response characterized by increased expression of CRP genes in liver and heart tissues after 18 weeks when compared with the control rats that showed no expression for the gene. (Analysis of images to show the peak). Tissue-specific gene expression is regulated at the transcriptional initiation step through the recognition of promoter sites by transcription factors (Maniatis et al., 1987). This general scheme for tissue-specific gene expression has been documented for many cell types, including pancreatic endocrine cells, hepatocytes (De Simone \& Cortese 1988), erythrocyte, muscle cells (Lassar et al, 1989) and B cells (Muller et al, 1988). It seems likely therefore that the expression of the mouse acute-phase genes is regulated by liver-specific trans- acting factors and cis acting elements within the 5' flanking region of the genes (Namon \& Richard, 1993).

In conclusion, the present stydy confirms a role of CRP in atherosclerosis, supporting and extending previous observations of potentially proatherogenic action of CRP in vitro. Also we conclude that CRP is not merlly a risk marker for but also an active participant of atherogenesis in vivo.

Lipopolysaccharide-binding protein (LBP) was proposed as an additional marker for Coronary Artery Disease (CAD) risk, because LBP can be regraded as a surrogate marker for activated innate immune system, which plays an important role in the pathophysiology of atherosclerosis. Owing to the economic burden and often devastating consequences for the individual caused by the sequelae of atherosclerosis, it is highly desirable to have reliable biomarkers for the development and/or progression of atherosclerosis. In the past, several markers have been discussed, and C-reactive protein (CRP) has been proposed as a reliable marker for atherosclerosis (Pepys \& Hirschfield, 2003). Because LBP is similar to CRP, both being acute-phase proteins, we tested the hypothesis that LBP might be able to be used as a biomarker for coronary artery disease $(\mathrm{CAD})$ in comparison.

As an acute phase response, protein LBP is especially interesting because of findings 


\section{Comparison of Lipopolysaccharide binding protein and C-reactive protein....}

indicating a potential dual role in the regulation of LPS action on target cells: low baseline level concentrations of LBP have been shown to enhance LPS potency, whereas the high concentrations seen during the acute phase can decrease the suppressive effect of LPS by shunting it into the HDL clearance pathway. It has been demonstrated in a mouse model that the high serum concentrations of LBP are protective in the setting of sepsis and bacteremia (Whitehead, 1990). LBP is present at low levels (ca. 100-200 ng/ml in the blood) under normal conditions whereas it is highly increased during infections (ca. 10-20 $\mu \mathrm{g} / \mathrm{ml}$ ) to neutralize LPS for the prevention of overwhelming inflammation (Zweigner et al., 2001).

Liver is considered to be the central organ regulating this acute phase response by releasing specific acute phase protein including LBP which has been defined as a class I acute phase protein.. Previous data showed that LBP mRNA expression in liver and kidneys markedly increased after burns.

(Marnell et a.l, 2005) LBP expression in several cell types was demonstrated to be dramatically up-regulated by exposure to proinflammatory cytokines including IL-1 $\beta$, IL-6, and TNF- $\alpha$. (Calabro et al., 2003). Because LBP is the first protein to encounter LPS and to deliver it to its cellular targets, it seems to be the first step in this proinflammatory cascade (Schumann et al., 1994); therefore, its presence might be a reliable biomarker that indicates activation of innate immune responses. It might qualify as an excellent marker for activation of innate immunity.

Our data showed expression for LBP genes by hepatocyte after 18 weeks of cholesterol feeding, while no expression in the heart tissue. However rat liver LBP expression levels markedly decreased and became less than that of control. These findings are in harmony with those of (Usui et al., 1998), which stated that LBP gene expression occur in tissues such as liver, kidney, spleen and lung was reported in rat. Also, this agree with the studies of Schumann et al.( 1994) as they reported that rat LBP mRNA is expressed mainly in the liver and slightly in kidneys and lungs, and that its levels increase markedly in the liver, kidneys and lungs in bacterial infections. Rat and rabbit models as well as experiments with primary human hepatocytes and human hepatoma cell lines demonstrated that LBP is a secretory class 1 acute-phase protein whose gene is transcriptionally activated by the acute-phase response element/signal transducer and activator of transcription 3 (APRF/STAT3) and other cytokine-inducible nuclear proteins, where Our study indicated that the predicted signal $\mathrm{p}$ for the predicted protein sequence of rat LBP is a non-secretory protein Dentener et al.( 2000) . 


\section{Kholoud S. Ramadan... et Al}

There was no expression for LBP genes in normal rat's liver in our study. These findings can be supported by the findings of Dentener et al.( 2000) which stated that the transcriptional regulation of the LBP gene is induced by interleukin (IL)-1 alone or synergistically by IL-1 and IL-6, leading to a maximal LBP concentration within 24-48 h after stimulation, a response that can be strongly enhanced by tumor necrosis factor (TNF)-a and dexamethasone (Whitehead $\boldsymbol{e t}$ al., 1990).

Serum amyloid $\mathrm{P}$ component (SAP) is a member of pentraxins. Previous studies indicate that SAP exists in human atherosclerotic aortic intima and the plasma SAP levels are associated with cardiovascular disease (Hirano et al., 1990) .SAP is produced mainly in the liver and secreted into the blood circulation. The average plasma concentration of SAP is about $40 \mathrm{mg} / \mathrm{l}(160$ $\mathrm{nM}$ ) in human (Puranik et al., 2005). In man and rabbit, one of the serum proteins that exhibit the highest proportional increase, from trace resting levels to several hundred micrograms per $\mathrm{ml}$, is CRP. SAP is a relatively low concentration constitutive serum protein in man. Paradoxically, in mouse SAP is a 'major' acute phase reactant, increasing from resting levels of around 60, $\mu \mathrm{g} / \mathrm{ml}$ or less to peak concentrations of several hundred micrograms/ml during acute inflammation (Gabay, 1999). Although mouse
CRP is poorly defined, it has been reported as a trace serum component (Shioi et al., 1996) that increases slightly in concentration during the acute-phase response .These studies support our present study where by analysis of our PCR product images for both CRP and SAP genes expression in liver tissue, we found that the relative density for SAP genes bands was higher than that of CRP genes bands which gives a confirmed figure about that SAP represent the major acute phase protein in rat (Saito et al., 1992).

Numerous studies using primary mouse hepatocytes have shown that the mouse SAP gene can be induced by the direct action of either IL-1 or IL-6. Thus, both CRP and SAP are usually considered to be class 1 acutephase gene products (Lin et al., 1990).

Serum levels of SAP in mouse start to rise approximately $8 \mathrm{~h}$ after an acute-phase stimulus and peak at 24-48 h (Pepys \& Hirschfield 2003) the serum half-life is $7-8 \mathrm{~h}$ and is independent of the SAP level (Baltz et al., 1985). Increases are therefore proportional to the rate of synthesis and secretion of SAP rather than to changes in clearance. One of the most potent stimuli to SAP production is bacterial endotoxin. Recently it has been shown that this effect is mediated via certain cytokines produced by activated monocytes and macrophages (Le et al., 1982). 


\section{Comparison of Lipopolysaccharide binding protein and C-reactive protein....}

In this study, the data showed that there was no expression for SAP genes in normal rat's liver while SAP expression markedly increase in liver tissue after induction of atherosclerosis. Also, in the present study, no expressions for SAP genes were observed in heart tissue after atherosclerosis induction when compared to the control. These findings are contradicted with those of Zhiqing $\boldsymbol{e t}$ al. (2010) which indicates that SAP is produced by non-hepatic cells.

In summary, our data demonstrate that in atherogenic rats, the expression of SAP is rapidly and strongly in liver parenchyma but not in the heart during the atherosclerosis induced acute phase response. In this regard, SAP might be referred to as an early intracellular acute phase protein. Taken together, these data point to an important role of SAP in cytoprotection of hepatocytes, which might become damaged during their intensive function under inflammatory conditions.

The synthesis of all known types of collagen depends on prolyl 4-hydroxylase (P4H), a key intracellular enzyme. $\mathrm{P} 4 \mathrm{H}$ has $\alpha$ and $\beta$ subunits: the $\alpha$ subunit is rate limiting and essential for collagen maturation and secretion. The subunit folds the procollagen polypeptide chains into stable triple helical molecules. Inhibition of $\mathrm{P} 4 \mathrm{H}$ produces unstable collagen associated with a decreased level of collagen. Cytokines, including various interleukins, TNF- $\alpha$ and transforming growth factor beta, may participate in ECM metabolism by decreasing the activity of the type I isoenzyme of $\mathrm{P} 4 \mathrm{H}$. However, there are no data about the defense molecules regulating the activity of $\mathrm{P} 4 \mathrm{H} \alpha 1$. $\mathrm{P} 4 \mathrm{H} \alpha 1$ is associated with atherosclerotic plaque rupture. Several studies have revealed that various cytokines, such as interleukins and TNF- $\alpha$, inhibit the P4H isoenzymes. Zhang et al. (2007) reported that TNF- $\alpha$ suppresses collagen synthesis by specifically inhibiting $\mathrm{P} 4 \mathrm{H} \alpha 1$, and Raveendran et al. also showed that cigarette smoke extract can significantly downregulate the expression of $\mathrm{P} 4 \mathrm{H} \alpha 1$. However, little information exists on whether the defense molecules regulating the expression of $\mathrm{P} 4 \mathrm{H} \alpha 1$ play a key role in plaque cap stability (Li et al., 2010).

Because adiponectin is a defense molecule in plasma, it might play a protective role in atherosclerosis by inducing $\mathrm{P} 4 \mathrm{H}$ expression. mRNAs of all isoforms of $\mathrm{P} 4 \mathrm{H}$ were detectable in heart, liver, kidney, brain, testis and lung. In normal animals, highest levels for PHD2 mRNA and PHD3 mRNA were found in myocardium, whereas PHD1 mRNA was detected predominantly in the testis. PHD1 mRNA was constitutively expressed. PHD2 mRNA was induced by hypoxia in the liver and PHD3 mRNA in liver, testis and heart (Walsh, 2009).

$\mathrm{P} 4 \mathrm{H}-\beta$ gene showed expression by hepatocytes in atherosclerotic groups after 18 weaks of 
cholesterol feeding. While P4H- $\beta$ gene shows no expression in the heart of atherosclerotic groups as the normal control group. After 18 weaks of cholesterol feeding, the rat $\mathrm{P} 4 \mathrm{H}-\beta$ gene expression recorded high level compared to the control, in liver. In heart, rat $\mathrm{P} 4 \mathrm{H}-\beta$ gene showed no expression in atherosclerotic groups as in normal contorl group.

\section{Conclusion:}

As a result of this study it can be said that CRP has important role in atherosclerosis, it is not merly a risk marker for but also an active participant of atherogenisis in vivo. LBP is a non-secretory protein, its expression decreased and became less than control in liver atherogenic rats with no expression in heart tissue. Also, the study point to an important role of SAP in cytoprotection of hepatocytes.

Annunen P, Autio-Harmainen $\mathbf{H}$ and Kivirikko KI (1998): The novel type II prolyl 4-hydroxylase is the main enzyme form in chondrocytes and capillary endothelial cells, whereas the type I enzyme predominates in most cells. J Biol Chem ; 273: 5989-5992.

Ballou S p and Kushner I (1992): C-reactive protein and the acute phase response. Adv. Intern Med., : 313-337.

Baltz ML, Dyck RF and Pepys MB (1985): Studies on the in vivo synthesis and catabolism of serum amyloid $\mathrm{P}$ component (SAP) in the mouse. Clin. exp. Immunol., 59: 235.

Banchroft JD, Stevens A and Turner DR (1996): Theory And practice Of Histological
Techniques. Fourth Ed. Churchil Livingstone, New York, London, San Francisco, Tokyo.

Black S, Kushner I, Samols D (2004): Creactive protein. J Biol Chem., 279:4848748490.

Calabro` $P$, Willerson JT and Yeh ET (2003): Inflammatory cytokines stimulated Creactive protein production by human coronary artery smooth muscle cells. Circulation, 108: 1930-1932.

Castell JV, Gomez-Lechon MJ, David M, Fabra R, Trullenque $R$ and Heinrich PC (1990): Acute-phase response of human hepatocytes: regulation of acute-phase protein synthesis by interleukin-6. Hepatology, 12(5):1179-86.

Collins R, Armitage J, Parish S, Sleight $\mathbf{P}$ and Peto R(2004): Heart Protection Study Collaborative Group. Effects of cholesterollowering with simvastatin on stroke and other major vascular events in 20536 people with cerebrovascular disease or other high-risk conditions. Lancet; 363: 757-67.

De Simone $V$ and Cortese $R$ (1988): Extracoronary atherosclerosis in familial hypercholesterolemia. Atherosclerosis 1988;71:205-213.

Dentener MA, Vreugdenhil AC, Hoet PH, Vernooy JH, Nieman FH, Heumann D, et al. (2000): Production of the acute-phase protein lipopolysaccharide-binding protein by respiratory type II epithelial cells: implications for local defense to bacterial endotoxins. Am J Respir Cell Mol Biol; 23:146-53.

Gabay C (1999): Acute-phase proteins and other systemic responses to inflammation. $\mathrm{N}$ Engl J Med, 340:448-454.

Hirano T, Matsuda T, Turner M , Miyasaka N, Buchan G, Tang B, Sato K , Shimizu M, Maini R, Feldmann M et al. (1988): Excessive production of interleukin 
6/B cell stimulatory factor-2 in rheumatoid arthritis. Eur J Immunol; 18: 1797-1801.

Jiang SL, Samols D, Rzewnicki D et al. (1995): Kinetic modeling and mathematical analysis indicate that acute phase gene expression in Hep 3B cells is regulated by both transcriptional and posttranscriptional mechanisms. J Clin Invest, 95: 1253-1261.

Kolz W, Koenig W, Muller M, Andreani M, Greven S, Illig T, Khuseyinova $\mathbf{N}$, Panagiotakos D, Pershagen G, Salomaa V, Sunyer J, and Peters A (2008): DNA variants, plasma levels and variability of $\mathrm{C}$ reactive protein in myocardial infarction survivors: results from the AIRGENE study. European Heart Journal, 29:1250-1258.

Lassar AB, Buskin JN, Lockshon D, Davis, RL, Apone S, Hauschka SD and Weintraub H (1989): $M y o D$ is a sequence-specific DNA binding protein requiring a region of myc homology to bind to the muscle creatine kinase enhancer.Cell, 58: 823-831.

Le PT, MT. Muller and RF and Mortensen (1982): Acute phase reactants of mice. I. Isolation of serum amyloid P-component (SAP) and its induction by a monokine. $J$. Immunol. 129:665.

Li L, Cai XJ, Feng M, Rong YY, Zhang Y and Zhang $M$ (2010): Effect of adiponectin overexpression on stability of preexisting plaques by inducing prolyl-4-hydroxylase expression., Circ J.;74(3):552-9.

Libby P (2002): Inflammation in atherosclerosis. Nature, 420: 868-874.

Li BF, Ku NO, Zahedi K, Whitehead, AS and Morensen R F (1990): IL-1 and IL-6 mediate increased production and synthesis by hepatocytes of acute-phase reactant mouse serum amyloid P-component (SAP). Inflammation, 14:297-313.
Lusis AJ (2000): Atherosclerosis. Nature; 407: 233-241.

Maniatis T, Goodbourn S and Fischer JA (1987): A Laboratory Manual. Cold Spring Harbor Laboratory, Cold Spring Harbor, NY. 38. Sigal, E., C. S. Craik, E. Highland, D. Grunberger, L. L. Costello, R. A. F. Dixon, and J. A. Nadel. 1988. Molecular cloningand primary structure ofhuman 15lipoxygenase.Science, 236: 1237-1245.

Marnell L, Mold C and Du Clos TW (2005): C-reactive protein: ligands, receptors and role of inflammation. Clin Immunol., 117:104-111.

Muller MM, Ruppert S, Schaffner W and Matthias, $P$ (1988): The characteristics and metabolism of a genetically hypercolesterolaemic strain of ratsNature (London) 336: 544-551.

Nam-on KU and Richard F and Mortensent (1993): Cloning and tissue-specific expression of the gene for mouse C-reactive Protein. Biochem. J., 295: 379-386.

Nicholas FM (2004): RNA extraction from human or animal tissue samples. The institute for genomic research standard operating procedure. SOP \#: M019: 1-12.

Paul A, Ko KW, Li L, Yechoor V, McCrory MA, et al. (2004): C-reactive protein accelerates the progression of atherosclerosis in apolipoprotein E-deficient mice. Circulation 109: 647-655.

Pepys MB and Hirschfield GM (2003): Creactive protein: a critical update. J Clin Invest. ;111:1805-1812.

Puranik R, Chow CK, Duflou JA, Kilborn MJ and McGuire MA (2005): Sudden death in the young. Heart Rhythm 2:1277-1282. 
Saber AT, Halappanavar S, Folkmann JK. et al. (2009): Lack of acute phase response in the livers of mice exposed to diesel exhaust particles or carbon black by inhalation. Paeticle and Fibre Toxicology, 8977:6-12.

Saito M, Yoshida K, Hibi M, Taga T and Kishimoto T (1992): Molecular cloning of a murine IL-6 receptor-associated signal transducer, gp130, and its regulated expression in vivo. J. Immunol. 148: 4066-4071

Schumann RR, Leong SR, Flaggs DW, Gray PW, Wright SD, et al. (1994): Structure and function of lipopolysaccharide binding protein. Science, 249:1429-1431.

Shehata AM and Yousef OM (2010): Physiological Studies on the Risk Factors Responsible for

Atherosclerosis in Rats. Nature and Science ,8(5):144-151.

Shioi T, Matsumori A and Sasayama $S$ (1996): Persistent expression of cytokine in the chronic stage of viral myocarditis in mice. Circulation, 94: 1930-1937.

Usui M, Hanamura N, Hayashi T, Kawarada $Y$ and Suzuki $K$ (1998): Molecular cloning, expression and tissue distribution of canine lipopolysaccharide (LPS)-binding protein. Biochem. Biophys. Acta, 1397: 202-212.
Walsh K (2009): Adipokines, Myokines and Cardiovascular Disease. Circ J ; 73: 13-18.

Whitehead AS, Zahedi M, Rits RF, Mortensen JM and Lelias (1990): Mouse Creactive protein: generation of complementary DNA clones, structural analysis, and induction of messenger RNA during inflammation. Biochem. J., 266:238-290.

Zhang C, Zhang MX, Shen YH, Burks JK, Zhang Y, Wang J, et al.(2007): TNF- $\alpha$ suppresses prolyl-4-hydroxylase $\alpha 1$ expression via the ASK1-JNK-NonO pathway. Arterioscler Thromb Vasc Biol ., 27: 17601767.

Zhiqing S, Lei C, Ling G, Yoshitane T, Chikao $Y$ and Xiang A (2010): Accumulation and expression of serum amyloid $\mathrm{P}$ component in human atherosclerotic lesions. Atherosclerosis ,211:90-95.

Zweigner J, Gramm HJ, Singer OC, Wegscheider $K$ and Schumann RR (2001): High concentrations of lipopolysaccharidebinding protein in serum of patients with severe sepsis or septic shock inhibit the lipopolysaccharide response in human monocytes. Blood, 98: 3800-3808. 
Comparison of Lipopolysaccharide binding protein and C-reactive protein....

\section{مقارنة التعبير الجيني لكل من البروتين الرابط للسكريات الاهنية العديدة}

\section{و البروتين المتفاعل (ج) في نماذج من الفئران المصابة بتصلب الثرايين}

"1خود صلاح الدين رمضان , 1رشا الثريف حسن, 1عبد الرحمن عبد الغفار ,1أسماء عبد الفتاح دغيدي

*1قسم الكيمياء الحيوية_كلية العلوم للبنات_جامعة الملك عبد العزيز -جدة_المملكة العربية السعودية. 1قسم الكيمياء الحيويةـ كلية العلوم- جامعة عين شمس-القاهرة.

أن تصلب الثرايين هو رد فعل إلتهابي مزمن في بطانة الأو عية نتيجة لزيادة نسبة الدهون و التي تسبب

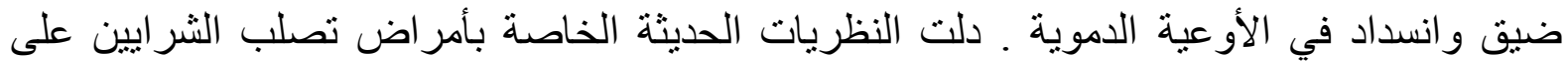
وجود عو امل كثثرة مؤثرة على حدوث وتطور المرض منها إرتفاع الضغطة، إرتفاع تركيزات البروتين

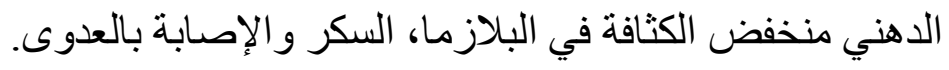

الهرف من هذا البحث هو تقييم العلاقة بين التعبير الجيني لرنا الناقل الخاص بكل من البروتين الرابط

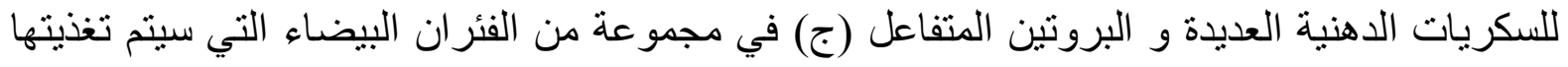

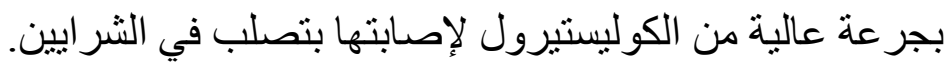

شملت هذه الدر اسه 30 فأر تجارب قسمت إلى مجموعتين: المجموعة الأولي ( 10) تم تغذيتهم بالغداء

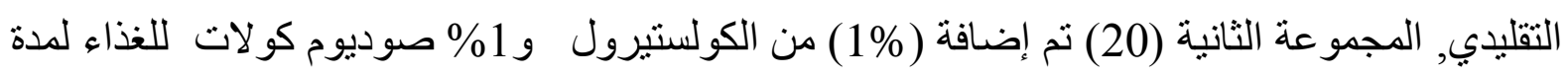
(18 اسبوع) لإصابتهم بتصلب في الثر ايين. وتأكد حدوث المرض عن طريق الفحص الهيستو باثولوجي.

تم عزل رن ا من القلب ,عمل تفاعل البلمرة الناسخ العكسي للحصول على دن ا المكل, تصميم بادئات, تفاعل البلمرة المنسلسل, الفصل الكهربائي. كما تم أيضا كلونة وعمل متتابعة للجينات

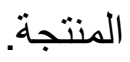

أسفرت النتائج عن التعبير الجيني لكل من البروتين المتفاعل (ج) في الكبد والقلب بينما باقي الجينات في الكبد فقط. 